Identifying the Macroeconomic Effect of Loan Supply Shocks

By Joe Peek*

Eric S. Rosengren***

and

Geoffrey M.B. Tootell $* * *$

\begin{abstract}
Evidence of an operative credit channel has been inconclusive. The inability to clearly distinguish the effects of shocks to loan supply from those to loan demand has made it difficult to quantify the importance of this transmission mechanism to the economy. This paper provides an innovative approach to identifying loan supply shocks that enables us to show that such disturbances have had economically important effects on the U.S. economy over the past two decades. We provide three different pieces of evidence that confirm that loan supply shocks have been successfully isolated from shifts in loan demand: Our measure is particularly important for explaining inventory movements, the component of GDP most likely to be sensitive to shifts in bank loan supply; the effect is present even during periods of strong loan demand; and the effect does not dissipate quickly, as would be the case for demand shocks.
\end{abstract}

***Research Department, T-8, Federal Reserve Bank of Boston, 600 Atlantic Avenue, Boston, MA 02106, (617) 973-3090, fax: (617) 973-2123, Eric.Rosengren@ bos.frb.org and Geoffrey.Tootell@bos.frb.org

*Department of Economics, Boston College, Chestnut Hill, MA 02467, (617) 552-3686, fax: (617) 973-2123, Peek@bc.edu

We thank Peggy Gilligan and Peter Morrow who provided valuable research assistance. The views expressed are those of the authors, and do not necessarily reflect official positions of the Federal Reserve Bank of Boston or the Federal Reserve System. 


\section{Identifying the Macroeconomic Effect of Loan Supply Shocks}

Despite widespread debate, the role of the credit channel in the transmission of monetary policy remains unresolved. On a conceptual level, broad agreement exists on how this channel might operate, but the evidence about its actual impact on the real economy has been inconclusive. Skepticism about the practical importance of this channel follows two basic tacks. First, some have argued that monetary policy shocks fail to affect bank lending, thus making this channel inoperative. Second, it has been argued that even if bank lending is affected, such changes still might not have an independent effect on the macroeconomy, since firms are able to obtain credit from sources other than banks. Because doubts about the existence of an operative credit channel have focused primarily on this second issue, most empirical studies have considered whether shocks to the supply of bank loans affect the real economy. Unfortunately, the empirical literature has failed to answer this question convincingly, since it has been unable to satisfactorily untangle loan supply shocks from disturbances to loan demand; decreases in bank lending can occur either because weakened firms demand less credit or because banks are cutting back on loans. This paper controls for changes in loan demand more effectively and isolates loan supply shocks more precisely, through a combination of a better measure of loan supply shocks and the use of methods that can better identify the effects of these disturbances. The results clearly show that loan supply shocks do have significant effects on the macroeconomy, both in the sectors and in the manner one would expect if a credit channel were operative.

Previous studies have followed two basic strategies for distinguishing loan supply shocks from loan demand shocks. The first has utilized economy-wide variables, such as the mix of bank loans and commercial paper, interest rate spreads, total bank loans, or loans under 
commitment, to identify shifts in loan supply (Bernanke 1983; Bernanke and Blinder 1992; Kashyap, Stein, and Wilcox 1993; Kashyap, Lamont, and Stein 1994; Kashyap and Stein 1994, 1995; Morgan 1998). However, approaches using aggregate data have been criticized for not controlling adequately for loan demand (Oliner and Rudebusch 1996). In response to this criticism, much research has focused on bank-level and firm-level data (Carpenter, Fazzari, and Petersen 1994, 1998; Gertler and Gilchrist 1994; Kashyap and Stein 2000). The hope was that these disaggregated data sets would be able to better control for loan demand by comparing the reactions of non-bank-dependent borrowers to those of bank-dependent borrowers. Yet clearly identifying either the degree of bank dependence of particular firms or the types of customers at particular banks has been problematic. Furthermore, these studies are subject to the criticism that aggregate demand fluctuations might disproportionately affect bank-dependent firms and thus disproportionately affect loan demand by these firms, making the distinction inadequate for isolating loan supply shocks from shifts in loan demand. A final problem with firm-level approaches is that they fail to directly measure the macroeconomic significance of any effect (Ramey 1993).

This paper presents several innovations to the empirical examination of the role of bank lending in the macro economy. First, unlike the previous literature, model-driven commercial forecasts of real economic activity are used to control for loan demand. Since the models used by commercial forecasters are much richer than those used in previous macro research in this area, the ability to control for changes in loan demand is much more complete. Commercial forecasts more effectively account for aggregate demand, and tests of their efficiency show that they contain all publicly available information about the state of aggregate demand (and supply). 
And since a firm's demand for loans depends crucially on the demand for its products, the ability to account for aggregate demand is essential to controlling for loan demand.

Loan supply shocks also are measured in a new way, one that avoids two serious problems associated with earlier tests. Previous studies at the macro level correlate changes in measures of firm or bank activities with measures of shifts in monetary policy. As is well known, the identification of monetary policy shocks presents its own set of difficulties (Bernanke and Mihov 1998; Hoover and Perez 1994; Leeper 1997; Romer and Romer 1990), which have been largely ignored in the credit channel literature. Perhaps even more problematic, whatever the method used to identify monetary policy shocks, these disturbances are, by their very nature, correlated with shifts in loan demand. Any decline in bank loans associated with a tightening of monetary policy could be caused either by a cutback in lending by banks or by a decline in loan demand brought on by the weaker economy working through the other channels of monetary policy. Definitive evidence of an operative lending channel requires a solution to these two problems.

These two difficulties are sidestepped in this paper by using confidential supervisory information on aggregate bank health as a proxy for loan supply shocks. By using a direct measure of disturbances to loan supply, we avoid the need to identify shifts in monetary policy in order to test for the effects of loan supply shocks on the economy. Furthermore, the ensuing test avoids the identification problems associated with using a loan supply shock measure that is, by its very nature, correlated with changes in loan demand. The confidentiality of the variable also satisfies the requirement that the information not be incorporated into the commercial forecasts included to control for loan demand effects. Thus, any effect of this bank health variable on 
output represents a cleaner measure of loan supply effects on aggregate activity than is found in the previous literature.

These improvements in the method for controlling for shocks to loan demand and the measurement of disturbances to loan supply are incorporated in three different sets of tests that provide compelling evidence that the effect of shocks to bank loan supply on the real economy has been identified. These further tests are necessary because, even though commercial forecasts of GDP control for demand shocks on average, in the short run they fail to account completely for these disturbances - errors are made. These short-run errors could be errors in loan demand, in addition to loan supply, which the bank health variable is capturing. This set of tests ensures that the bank health variable is capturing loan supply effects.

The first test is based on differences in the degree of bank dependence of the major components of GDP. If unexpected weakness in aggregate demand, and thus in loan demand, is correlated with our proxy for loan supply, then the bank health variable should significantly reduce forecast errors for most components of GDP, particularly the more endogenous ones. Yet, if the importance of the bank health variable is due solely to a loan supply effect, then this variable would primarily affect those GDP components for which bank lending is an important source of funds. Thus, if the effect of the loan supply proxy is robust across components of GDP, including both exogenous components (such as government spending) and endogenous components (such as consumption) that are not bank dependent but are highly correlated with aggregate demand shocks, then one might be skeptical that this test has adequately isolated loan supply shocks from shifts in loan demand. If, on the other hand, the impact of the bank health variable on specific components of GDP is related to the degree to which that component relies on bank financing, then the results would provide compelling evidence that a loan supply effect 
has been successfully isolated. In fact, we find a pattern that is consistent with loan supply effects. The change in real business inventories, which should be the GDP component most closely related to bank financing (Kashyap, Lamont, and Stein 1994), exhibits the strongest reaction to changes in bank health, while, at the other extreme, government expenditures exhibit no response.

Still, even if the effect were originating solely from bank-dependent components, such as inventory investment, the bank health variable might be capturing the effect of a cyclical decline in loan demand, one that disproportionately affects firms that hold inventories. Thus, as a second test, it is important to determine the extent to which this effect is sensitive to the business cycle. If the significance of the bank health proxy derives from periods of weak loan demand growth, such as recessions, then it could be capturing loan demand as well as loan supply effects. If, however, the bank health proxy retains its significant negative effect on economic activity even at times of high loan demand, then we can be confident that the variable has isolated loan supply effects. In fact, we find that our loan supply proxy affects the economy, and business inventories in particular, even when loan demand is high. Thus, the importance of this variable does not appear to be as a leading indicator of general economic weakness or, more specifically, of weak loan demand, but instead derives from the effect of bank lending on real economic activity.

The third test is based on Blanchard and Quah (1989) and uses the persistence of the effect of a shock to distinguish demand shocks from supply disturbances. For example, any errors in the inventory forecasts due to shocks to demand should be quickly unraveled and offset by both the firms and the economic forecasters. Supply shocks, on the other hand, should be more persistent, and confidential loan supply shocks could take a long time to be incorporated into forecasts. A rapid depreciation of the value of the information contained in the bank health 
variable would be consistent with it capturing a demand effect, while a persistent effect would indicate a loan supply shock. We find that the effects of bank health on both real GDP growth and the change in real business inventories persist, with the latter effect lasting for at least one year. As a result, one can confidently conclude that our measure of bank health is not serving as a proxy for loan demand or for firm health more generally, but for loan supply shocks.

The paper proceeds as follows. The next section describes the empirical design and how it avoids many criticisms of prior studies that examine the credit channel. The second section describes the results from examining how the bank health variable influences real GDP and its components. The final section concludes.

\section{Empirical Design}

While previous studies have tried to allay the potential identification problem, we utilize a much different empirical test in an attempt to clearly identify loan supply shocks. The empirical design of this paper is illustrated by a simple equation for the growth in real GDP:

1. $G D P_{t+i}=\alpha_{0}+\alpha_{1} E_{t}\left(G D P_{t+i} / \Omega_{t}\right)+\alpha_{2} L S_{t}+\varepsilon_{t}$

GDP growth in period $\mathrm{t}+\mathrm{i}$ is assumed to depend on shocks to loan supply, $\mathrm{LS}_{\mathrm{t}}$, as well as the myriad of other forces contained in the GDP growth forecast for period $t+i$ made at time $t$, $\mathrm{E}_{\mathrm{t}}\left(\mathrm{GDP}_{\mathrm{t}+\mathrm{i}} / \Omega_{\mathrm{t}}\right)$, based on the set of publicly available information at time $\mathrm{t}, \Omega_{\mathrm{t}}$. The inclusion of the forecast in the equation controls for all publicly known information about any demand or supply shocks - such as oil price movements, shifts in labor supply, changes in government spending, or past and expected future changes in the interest rate. As a result, the coefficient on 
the proxy for a loan supply shock in equation 1 is estimated controlling for the important variables that explain the growth in real GDP and, thus, any publicly known information about factors that would cause shifts in loan demand.

Since the forecast includes all publicly known disturbances, using forecasts as a control variable actually decreases the probability that a loan supply effect will be evident. Only if the loan supply shock is not publicly known, and thus not incorporated into the forecast, will it have an independent effect. That is, only to the extent that a change in bank health cannot be deduced from publicly available information will our proxy have a significant estimated coefficient. Complicating the matter, the effect of any loan supply shock should spread through the economy over time. Given this gradual effect, one way to test for the role of loan supply shocks on the economy is simply to use lags of the loan supply proxy in equation 1 . Yet such a specification would compound the problem with the possible dissipation of the confidentiality of the bank supervisory information. If the effect of the shock takes time to manifest itself in changes in output, simply lagging the bank health variable may not show an effect when using the forecast as a control variable, since by the time forecasts are made for the affected quarter, the bank supervisory information may have become known to the forecaster. To get around this problem, we examine individually the quarterly growth rates for each of the four quarters following a forecast date; that is, the actual growth rates associated with the one-, two-, three-, and fourquarter-ahead forecast horizons. Since the effect of the shock may take time to manifest itself in macro activity, the effect should be evident in the out-quarters of the forecast. Examining this range of forecast horizons allows us to untangle the effect of the loan supply shock from the duration of the confidentiality of the supervisory information. 
Equation 1 is estimated separately for the one-, two-, three-, and four-quarter-ahead forecasts using the Federal Reserve's own internal forecasts (the Green Book) and three major commercial forecasters: Data Resources, Inc.-McGraw Hill (DRI), Georgia State University (GSU), and the University of Michigan Research Seminar in Quantitative Economics (RSQE). All three private forecasters sell their forecasts commercially and have generally been among those with the best forecast record for the macroeconomic variables examined in this study (McNees 1992). Both RSQE and GSU provide quarterly forecasts that generally are released in the middle month of each quarter. The Federal Reserve Green Book forecasts are at Federal Open Market Committee meeting frequency, which ensures at least one forecast per quarter. When a quarter contains more than one Green Book forecast, we use the one closest to the middle of the quarter. DRI provides forecasts monthly, and we use their forecast for the middle month of each quarter, so that all forecasters possess roughly the same information set.

The proxy for the loan supply shock is based on the confidential CAMEL ratings used by bank examiners to rate individual banks. The composite CAMEL scores given to banks are based on the five categories supervisors analyze when evaluating the health of a bank: $\underline{\text { Capital, }}$ Assets, Management, Earnings, and Liquidity. ${ }^{1}$ Each bank is rated from 1, the highest, to 5, the lowest, on each of the component categories and given a composite rating. Banks with a composite rating of 1 (sound in every respect) or 2 (fundamentally sound) are not likely to be constrained in any way by supervisory oversight. Banks with a 3 rating (flawed performance) are likely to have potential problems raised by examiners, but these problems are usually viewed as being correctable. Banks with a CAMEL rating of 4 (potential of failure, impaired viability) have a significant risk of failure. Banks with a CAMEL rating of 5 (high probability of failure, severely deficient performance) represent the set of banks with the most severe problems. In 
fact, Peek and Rosengren (1995) show that banks cut back on lending as bank health deteriorates. Thus, the variable that serves as our proxy for the confidential bank health data (CAMEL5) is the assets of all commercial and savings banks with a CAMEL rating of 5 measured as a percentage of the total assets of all commercial and savings banks with a supervisory rating. We use the value for the end of the month prior to the forecast, for example, January 1990 for forecasts made in February 1990.

The confidentiality of the supervisory data is essential to this test. Since with efficient forecasts it is only unobservable (to the public) shocks that produce forecast errors, it is critical to identify a proxy for loan supply shocks that is not known to the public. Bank regulators consider bank supervisory information as being extremely confidential, since they historically have viewed banks as vulnerable to a public backlash if adverse supervisory data were released. However, not all of the information contained in CAMEL ratings remains confidential, since some information on bank health is released to the public through statements by bank management and quarterly income and balance sheet data (with a lag) and, for publicly traded banks, through SEC filings and bank analyst ratings. Still, Berger, Davies, and Flannery (2000) and DeYoung, Flannery, Lang, and Sorescu (1998), among others, find strong evidence that the confidentiality persists. $^{2}$ Thus, the predictable component of CAMEL5 should be incorporated in the GDP forecasts, leaving CAMEL5 to serve as a proxy only for that part of the change in bank health that is unobservable by the public.

Finally, the error term in equation 1 is not assumed to be independent and identically distributed. All forecasters tend to miss major macroeconomic surprises, producing errors that exhibit contemporaneous correlations across forecasters. Furthermore, since such macro surprises are sometimes late in the forecast horizon, the errors could be correlated across time. 
We use procedures suggested by Keane and Runkle (1990) to address the potential problems with inconsistent estimates of coefficient standard errors caused by these contemporaneous and intertemporal cross-correlations in the error term. The potential correlations in the errors also dictate the way the forecasts are lined up. Since several of the forecasts are published only toward the middle of each quarter, while others are produced monthly, we use the monthly forecast from the middle month of each quarter. ${ }^{3}$ This timing convention also ensures that all the forecasters know the U.S. Bureau of Economic Analysis (BEA) preliminary estimate of GDP for the prior quarter at the time the forecasts are made, eliminating the potential for a moving average process in the errors of the one-quarter-ahead forecasts. ${ }^{4}$

Table 1 provides the results from estimating equation 1 for real GDP growth. The sample begins in 1978:I, since the CAMEL data first became available in late 1977, and ends in 1998:IV. ${ }^{5}$ The coefficient on the proxy for loan supply shocks is estimated for each of the four one-quarter forecast horizons separately. The estimated coefficient on the bank health variable is negative for each of the four quarters, as expected, and statistically significant for the first two quarters. The estimated coefficients imply that as bank health deteriorates (the percentage of bank assets in CAMEL 5-rated banks increases), forecasters tend to overpredict real GDP - that is, GDP growth weakens with an adverse shock to loan supply. The estimated coefficients are also of economic significance. For example, a one-standard-deviation increase in CAMEL5 lowers actual GDP growth by 0.6 to 0.8 of a percentage point from what was expected in each of the first two quarterly forecasts. Since that pattern is not reversed during the subsequent two quarters, the level of real GDP remains permanently lower throughout the forecast horizon. 


\section{Identification of Loan Supply Shocks}

In a paper examining the usefulness and impact of bank supervisory information on monetary policy, Peek, Rosengren, and Tootell (1999a) show similar results to those in Table 1 for forecast errors of the unemployment and inflation rates. Although using forecasts is a more effective way to control for loan demand and using supervisors' ratings of bank health is a cleaner proxy for shocks to loan supply that are independent of shifts in loan demand, the significance of the CAMEL5 variable in either the GDP equation in Table 1 or the unemployment and inflation equations in Peek, Rosengren, and Tootell (1999a) still could be interpreted as suggesting that a deterioration in bank health is simply serving as a leading indicator of future weakness in the economy, and not that the state of bank health is causally related to economic activity.

Specifically, the information on deteriorating bank health contained in CAMEL5 could indicate a weakness of the firms that borrow from banks rather than a decline in the proclivity of banks to lend, a weakness that private forecasters do not pick up immediately since the information is not publicly available, and neither the bank nor the regulator has the incentive to make it so. Although more clearly specified than in previous research, this measure of a loan supply shock might still reflect shocks to loan demand in addition to shocks to the willingness of banks to lend. Thus, even though the forecast of GDP is controlling for the shocks to loan demand on average, the errors in the forecasts that are correlated with the bank health variable may represent instances when forecasters make a mistake about the strength of loan demand. High values of the bank health variable (weak bank health) may still be serving as a proxy for times when the economy, and loan demand, is unexpectedly weak. 


\section{Components of GDP}

This paper presents an exploration of the reasons for the significance of the loan supply proxy in the equations shown in Table 1. We begin by investigating the effect of the bank health variable on the major components of GDP. This decomposition helps identify the nature of the shock by testing whether the importance of the loan supply shock variable for GDP growth originates in components of real GDP for which bank lending is a significant source of financing. Specifically, this examination tests whether the regressions in Table 1 have successfully controlled for loan demand shocks. If the bank health variable were, in fact, capturing the effect on the forecast errors of shifts in loan demand, then the loan demand shocks could come from any component of GDP, whether that component was related to the activities of bank-dependent firms or not. If the loan supply proxy is capturing loan demand effects, or is simply serving as a leading indicator of changing economic conditions in general, then it should help predict all components of GDP, including exogenous components such as government spending and certainly including endogenous components such as consumption. If the proxy is capturing shocks to bank lending, it should directly affect the sectors for which bank lending is important and might have little effect on components not very reliant on bank financing.

As a result, we examine the effect of the proxy for loan supply shocks on the major components of real GDP, again using forecasts of these components as control variables for all publicly known demand and supply shocks. Table 2 presents the estimated coefficients on the loan supply proxy from these regressions. ${ }^{6}$ If the proxy variable is capturing only loan supply shocks, then the components should differ in their sensitivity to problems in the banking sector. In this case, the change in inventory investment should be the component that is most sensitive to loan supply shocks. This is especially true for most small firms, which rely on, and have few 
substitutes for, short-term credit from banks. Even for larger firms, the alternative sources of inventory financing are limited, insofar as insurance company and finance company lending tends not to be short-term, unsecured credit (Himmelberg and Morgan 1995). In fact, several studies have found an association between bank lending and inventory investment (Kashyap, Stein, and Wilcox 1993; Kashyap, Lamont, and Stein 1994). The least sensitive sector should be government spending.

The first row of Table 2 provides the results for the change in business inventories for each of the four forecast horizons. The estimated coefficients on the loan supply shock variable are negative, as expected, and statistically significant at all four forecast horizons. This evidence is consistent with the hypothesis that an adverse shock to loan supply (a higher value of CAMEL5), makes it more difficult for firms to obtain loans to finance inventories. Thus, when adverse loan supply shocks occur, forecasters tend to overpredict the change in business inventories. Since inventory movements account for much of the fluctuation in GDP (see, for example, Ramey 1989; Blinder and Maccini 1991), they are critical for understanding of the importance of banks to real economic activity.

The relationship between loan supply shocks and the other components of GDP should be much weaker. The next most likely candidates for an effect are the investment components. The estimated coefficients for the loan supply proxy in the nonresidential fixed investment regressions, while always correctly signed, are not significant for any of the four forecast horizons. In part, this result may be related to the importance of nonbank sources such as insurance companies and pension funds for financing nonresidential structures. For the investment in producers' durable equipment subcomponent, the estimated coefficients still are not significant at standard significance levels, although the estimated effects for the second- and 
third-quarter-ahead specifications are significant at the 10 percent level. These results are consistent with previous findings of a lack of a clear relationship between equipment investment and bank lending, perhaps in part because much of the investment in producers' durable equipment is undertaken by large firms that have easy access to sources of financing other than banks.

Residential investment could also be sensitive to bank lending. Although Bernanke and Gertler (1995) have emphasized that the bank lending effect should be visible in residential investment and consumer durable goods, there are several reasons to be skeptical about the importance of this transmission path. The sensitivity of residential investment would certainly have been much greater before the ascension of the secondary mortgage market, which opened the residential mortgage market more fully to nonbank lenders and made it into a national market. Now, when bank credit is tight, homeowners can go directly to mortgage brokers that resell the mortgages in the secondary market. As a result, this sector of the economy should be less sensitive to bank lending than before the 1980s (Edwards and Mishkin 1995). In fact, the estimated coefficient on the proxy for loan supply shocks is insignificant at each horizon for the residential investment equations.

Similarly, a number of factors suggest that consumer spending may not be particularly sensitive to shocks to bank lending. First, consumer lending for durable goods can occur through trade financing as well as bank lending. The other major source of consumer credit is credit cards. This market is highly liquid and national in scope. Furthermore, the personal tax deduction for consumer interest is now allowed only for real estate loans, so consumer borrowing occurs more and more in the form of mortgage credit, which the Table 2 results suggest is not particularly bank dependent. In fact, Table 2 provides little evidence that 
consumer spending is affected by loan supply shocks generated by changes in bank health. The estimated coefficients on the proxy for loan supply shocks are insignificant at each horizon.

Table 2 does show some mild evidence that loan supply shocks adversely affect exports, with three of the four estimated coefficients significant at the 10 percent level. One might have expected that exports would be less dependent on bank lending. Although the export business relies heavily on banks, export financing could occur from abroad, insofar as the importer obtains the credit. Furthermore, if exports are disproportionately produced by larger firms with access to sources of credit other than banks, they would be less sensitive to this type of shock. However, letters of credit and other credit enhancements frequently used in foreign trade are primarily serviced by internationally active banks. Thus, exports between U.S. firms and developing countries might be facilitated through the intermediation of U.S. banks. This could explain why there is at least weak support for bank health improving forecasts of real exports.

Finally, one would expect that government spending would not be susceptible to a loan supply shock. Since the government tends to purchase goods, such as weapons, from companies that are too big to be bank-dependent, or purchase labor services from the public, such as teachers, firefighters, and policemen, this sector should be relatively immune to disturbances to loan supply. In fact, firms with major orders from the government may be able to obtain loans more easily, since the risk to the lender is lower. Table 2 shows no evidence that loan supply shocks affect government spending; the estimated coefficient on the bank health variable is insignificant at each horizon.

The pattern of effects for the components of GDP provides strong evidence that the bank health variable is not simply correlated with demand errors in the forecasts. If the estimated effect derived from either aggregate demand generally or loan demand in particular, one would 
expect to find the effect to appear more broadly across the various GDP components, particularly in the more endogenous components. On the other hand, if the effect emanates solely from loan supply shocks, one would be more likely to find it only for the components that rely most heavily on bank financing, as is the case here. These results suggest that the bank health variable has isolated a loan supply effect, and that this loan supply proxy has important effects on economic activity.

Cyclicality of the Effect

The strong sensitivity of inventory investment to the bank health variable still could be capturing the effects of a decline in loan demand. Firms that hold inventories may be disproportionately hurt by economic downturns. Thus, the sensitivity of this effect to the stage of the business cycle is examined next. If a deterioration of bank health adversely affects the economy even at times of high loan demand, then we can be confident that the variable is capturing loan supply effects. However, if the bank health variable helps predict economic activity only during recessions, then it is less clear that the variable has successfully isolated the effect of loan supply shocks from those of shifts in loan demand.

In this section, the stability of the effect on the economy of the loan supply proxy across periods of recession and expansion is examined. In addition, the equations are estimated for a sample that is restricted to those observations when the economy is growing faster than the trend growth of potential GDP in order to investigate whether the effect is significant even when the economy is strong. If the negative estimated coefficients on the bank health variable are reflecting loan demand shocks, then one would expect the effect to emanate primarily from recession periods when loan demand is unusually low. On the other hand, if the variable has, in 
fact, successfully isolated the effects of a loan supply shock, then the negative effect on economic activity of weak bank health would be seen even when loan demand was relatively high. In fact, our sample includes periods when bank health was weak at the same time that aggregate demand was strong. Since the effect is centered in business inventories, we report results only for that component of GDP.

Table 3 presents the results for the change in business inventories using a specification similar to that in Table 2, but including two additional explanatory variables: a $(0,1)$ dummy variable with a value of one when the economy is in a recession (based on the NBER peak and trough dates) and an interactive variable equal to the product of the recession dummy variable and the bank health variable. ${ }^{7}$ This specification allows both the constant term and the slope coefficient for the loan supply shock proxy to have values that differ during recession periods. The former coefficient examines whether forecasts of inventories tend to miss in a systematic way during recessions, and the latter coefficient tests whether the proxy for a loan supply shock affects the economy differently during recession periods. If weakness in the bank health proxy is capturing the weakness in loan demand as the economy enters a recession, the total bank health effect should be negative during recessions and close to zero when the economy is expanding.

The results in Table 3 clearly indicate that the bank health proxy has a negative effect on the change in business inventories regardless of the state of the economy. The estimated effect of the recession dummy variable is negative and significant at the 10 percent level for the threeand four-quarter horizons, as would be expected if forecasters tended to miss the turning point as the economy enters a recession. The insignificant estimated coefficient on the recession differential for the bank health variable indicates that one cannot reject the hypothesis that the effect of the loan supply proxy is identical whether the economy is expanding or contracting. 
As a final test of the cyclicality of the effect, Table 4 presents the results for the business inventory regression estimated only for those periods when the economy was growing faster than the trend growth rate of potential GDP. The estimated coefficient on the proxy for loan supply shocks is correctly signed and statistically significant at each forecast horizon. Thus, even in periods of strong loan demand, an adverse loan supply shock weakens business inventory investment. This result provides strong evidence that the bank health proxy has successfully isolated loan supply shocks and is not capturing a cyclical loan demand effect.

\section{Duration of the Shock}

Our final test of the ability of the bank health proxy to isolate loan supply shocks from loan demand shocks is motivated by Blanchard and Quah (1989) and is based on an investigation of the duration of the loan supply shock effect on economic activity. Neither the marketplace nor the policymaker can quickly undo the effect of a supply shock. ${ }^{8}$ Therefore, supply shocks are more permanent, while the effects of a demand shock should dissipate quickly. The dissipation of the effect should be even more pronounced in this test because we are using forecasts as control variables. The effect of a demand shock will appear even more temporary because forecasters quickly become aware of a demand shock and incorporate it into their forecasts. For example, although forecasters do not excel at predicting turning points, they are quick to realize when the economy enters a recession. As a result, the duration of the confidentiality of the information contained in the bank health variable, and thus its effect in equations that use forecasts as control variables, should be very short if the bank health variable is serving simply as an indicator of demand, either aggregate or loan, rather than solely as a proxy for shocks to loan supply. ${ }^{9}$ 
Although the effect of a supply shock on the economy should persist, its effect on the forecast error should last only until forecasters become aware of the disturbance. For this test, however, even if a supply shock has persistent effects on the economy, it could still have only a temporary effect on the forecast errors if the supply shock becomes known to forecasters. However, since the supervisory data are confidential and therefore not known to forecasters, the contribution of the bank health information to reducing forecast errors should not dissipate quickly. ${ }^{10}$ A number of studies (Berger, Davies, and Flannery 2000; DeYoung, Flannery, Lang, and Sorescu 1998) have shown that the confidentiality of the supervisory ratings that serve as the basis of our bank health proxy persists. Peek, Rosengren, and Tootell (1999b) provide one explanation for such aggregate supervisory information to retain its confidentiality: The informational content of this variable is derived from those banks for which one would expect the information to leak out only very slowly, if at all - the small, non-market-traded banks. As a result, if the bank health variable reflects demand conditions, one would expect that any effect would be short-lived, as demand conditions are revealed as new information on sales, inventories, and profits become available. To the extent that the effects shown in the first four tables reflect (confidential) supply shocks to bank lending, the ability of that information to reduce forecast errors should not dissipate quickly.

Table 5 presents the results for a test that examines the duration of the effect of the bank health variable on forecast errors for real GDP growth and the change in business inventories. The base equations are reestimated 12 times, with the bank health variable replaced in turn by a single lagged value of itself, with the lags ranging from one to 12 months. The signs and significance of the estimated coefficients on the lagged bank health variable reveal that the improvement to commercial forecasts due to the information on loan supply shocks persists for 
quite some time. For one-quarter-ahead forecasts of real GDP, the bank health variable seven months old still provides important information. The effect is even more persistent for the change in business inventories. The bank health proxy from 12 months earlier still provides statistically significant information concerning the change in real business inventories. In forecasting the change in real business inventories two quarters ahead, a nine-month lag of the loan supply shock proxy still makes a statistically significant contribution to improving private sector forecasts. The durability of this effect provides strong confirming evidence that the bank health variable has successfully isolated the effects of loan supply shocks from those to loan demand.

\section{Conclusion}

The evidence in this paper provides compelling new support for the hypothesis that the credit channel is operative in the U.S. economy, and that loan supply shocks have had a significant impact on real macroeconomic variables over the past two decades. By utilizing an alternative methodology to identify loan supply shocks and control for changes in loan demand, new evidence is provided that supports the importance of an operative credit channel. Using a variable that directly measures bank health, rather than a proxy for monetary policy shocks, allows a cleaner identification of loan supply shocks. Using forecasts of economic activity better controls for loan demand. The importance of the bank health variable is strongest in the components of real GDP that are most bank dependent and the effect is not widespread across the major components of GDP, suggesting that the contribution of this variable does, in fact, derive from its role as an indicator of shocks to loan supply, rather than as an indicator of demand shocks to the economy as a whole, or to loan demand in particular. That the effect of 
the bank health variable is present even when loan demand is strong indicates that this variable has successfully isolated loan supply shocks from those to loan demand. Finally, the persistence of the bank health effect on economic activity signifies that the effect is reflecting loan supply shocks and is not serving as an indicator of aggregate demand in general or of loan demand shocks in particular.

These results also may have implications for the debate about the mechanism underlying the credit channel. Balance sheet effects, which manifest themselves through changes in asset prices and interest rate spreads, are incorporated in the forecasts used in this study as control variables, since information about the state of these pressures is readily available in the marketplace. However, the importance of the bank health variable suggests that a credit channel working through something other than interest rate differentials, or the level of the federal funds rate for that matter, is at work here. It also shows where that impact is largest, on business inventory investment, an area that previous research has indicated would be the component of GDP likely to be most affected by problems in the banking sector. In fact, the results suggest that some of the unexplained movement in inventories can be attributed to the effect of the credit channel, as hypothesized by Ramey (1993).

These findings are even more relevant for foreign policymakers. Countries as diverse as Japan, Ecuador, and Indonesia have recently spent a substantial fraction of their annual GDP to resolve problem banks. Such a large share of GDP would be hard to justify unless banking problems did create serious ramifications for the real economy. This research indicates that banking problems may indeed reduce economic growth, and that resolving those problems may be a necessary condition for economic recovery. It also highlights the importance of maintaining 
a healthy banking system, a point recently emphasized by the International Monetary Fund and the World Bank. 
Bibliography

Berger, Allen N., Sally M. Davies, and Mark J. Flannery. 2000. “Comparing Market and Supervisory Assessments of Bank Performance: Who Knows What When?" Journal of Money Credit and Banking, forthcoming.

Bernanke, Ben S. 1983. "Nonmonetary Effects of the Financial Crisis in the Propagation of the Great Depression." The American Economic Review, vol. 73, June, pp. 257-76.

Bernanke, Ben S. and Alan S. Blinder. 1992. "The Federal Funds Rate and the Channels of Monetary Transmission.” The American Economic Review, vol. 82, September, pp. 90121.

Bernanke, Ben S. and Mark Gertler. 1995. "Inside the Black Box: The Credit Channel of Monetary Policy Transmission." The Journal of Economic Perspectives, vol. 9(4), Fall, pp. 27-48.

Bernanke, Ben S. and Ilian Mihov. 1998. "Measuring Monetary Policy.” The Quarterly Journal of Economics, vol. 113, August, pp. 869-902.

Blanchard, Olivier and Danny Quah. 1989. “The Dynamic Effects of Aggregate Demand and Supply Disturbances.” The American Economic Review, vol. 79(4), September, pp. 65573.

Blinder, Alan S. and Louis J. Maccini. 1991. “Taking Stock: A Critical Assessment of Recent Research on Inventories.” Journal of Economic Perspectives, vol. 5, pp. 73-96.

Carpenter, Robert E., Steven M. Fazzari, and Bruce C. Petersen. 1994. "Inventory Investment, Internal-Finance Fluctuations, and the Business Cycle.” Brookings Papers on Economic Activity, No. 2, pp. 75-138. 
. 1998. "Financing Constraints and Inventory Investment: A Comparative Study with

High-Frequency Panel Data.” Review of Economics and Statistics, 80(4), November, pp. 513-19.

DeYoung, Robert, Mark J. Flannery, William W. Lang, and Sorin M. Sorescu. 1998. "The Informational Advantage of Specialized Monitors: The Case of Bank Examiners.” Federal Reserve Bank of Chicago Working Paper 98-4, August.

Edwards, Franklin R. and Frederic S. Mishkin. 1995. “The Decline of Traditional Banking: Implications for Financial Stability and Regulatory Policy.” Federal Reserve Bank of New York Policy Review, vol. 1(2), July, pp. 27-45.

Gertler, Mark and Simon Gilchrist. 1994. "Monetary Policy, Business Cycles and the Behavior of Small Manufacturing Firms.” The Quarterly Journal of Economics, vol. 109, May pp. $109-40$.

Himmelberg, Charles P. and Donald P. Morgan. 1995. “Is Bank Lending Special?” In Is Bank Lending Important for the Transmission of Monetary Policy? Joe Peek and Eric S. Rosengren, eds., Conference Series No. 39, Federal Reserve Bank of Boston, pp. 15-36. Hoover and Perez. 1994. "Post Hoc Ergo Propter Once More: An Evaluation of 'Does Monetary Policy Matter?' in the Spirit of James Tobin.” Journal of Monetary Economics, vol. 34, pp. 47-74.

Kashyap, Anil K and Jeremy C. Stein. 1994. "Monetary Policy and Bank Lending.” In Monetary Policy, N. Gregory Mankiw, ed., Chicago: University of Chicago Press. . 1995. "The Impact of Monetary Policy on Bank Balance Sheets." Carnegie-Rochester Conference Series on Public Policy, vol. 42, June, pp. 151-95. 
. 2000. "What Do A Million Banks Have to Say About the Transmission of Monetary

Policy?" The American Economic Review, forthcoming.

Kashyap, Anil K., Owen A. Lamont, and Jeremy C. Stein. 1994. "Credit Conditions and the

Cyclical Behavior of Inventories.” The Quarterly Journal of Economics, vol. 109,

August, pp. 565-92.

Kashyap, Anil K, Jeremy C. Stein, and David W. Wilcox. 1993. "Monetary Policy and Credit

Conditions: Evidence from the Composition of External Finance." The American

Economic Review, vol. 83, March, pp. 78-98.

Keane, Michael P. and David E. Runkle. 1990. “Testing the Rationality of Price Forecasts:

New Evidence from Panel Data." The American Economic Review, vol. 80, pp. 714-35.

Leeper, Eric M. 1997. "Narrative and VAR Approaches to Monetary Policy: Common

Identification Problems." Journal of Monetary Economics, vol. 40(3), December, pp. 641-57.

Morgan, Donald P. 1998. “The Credit Effects of Monetary Policy: Evidence Using Loan Commitments." The Journal of Money Credit and Banking, vol. 30(1), February, pp. 102-18.

Oliner, Stephen and Glenn Rudebusch. 1996. "Monetary Policy and Credit Conditions: Evidence from the Composition of External Finance: Comment." The American Economic Review, vol. 86, March, pp. 300-309.

Peek, Joe and Eric Rosengren. 1995. "Bank Regulation and the Credit Crunch.” Journal of Banking and Finance, vol. 19, June, pp. 679-92.

Peek, Joe, Eric S. Rosengren, and Geoffrey M. B. Tootell. 1999a. "Is Bank Supervision Central to Central Banking?" The Quarterly Journal of Economics, vol. 114, May, pp. 629-53. 
. 1999b. "Does the Federal Reserve Possess an Exploitable Informational Advantage?"

manuscript, September.

. 2000. "Synergies between Bank Supervision and Monetary Policy: Implications for

the Design of Bank Regulatory Structure.” In Frederic Mishkin, ed., Prudential

Supervision: What Works and What Doesn't? NBER, forthcoming.

Ramey, Valerie A. 1989. "Inventories as Factors of Production and Economic Fluctuations."

The American Economic Review, vol. 79(3), June, pp. 338-54.

. 1993. "How Important Is the Credit Channel in the Transmission of Monetary Policy?"

Carnegie-Rochester Conference Series on Public Policy, vol. 39, December, pp. 1-46.

Romer, Christina D. and David H. Romer. 1990. "New Evidence on the Monetary Transmission

Mechanism.” Brookings Papers on Economic Activity, No. 1, pp. 149-213. 


\section{Endnotes}

1. On January 1, 1997, the CAMEL rating system was expanded to CAMELS. The S stands for "sensitivity to market risk" and is intended to measure how well prepared a bank is to handle changes in interest rates, exchange rates, and commodity or equity prices. The CAMEL ratings for individual banks remain highly confidential. However, bank supervision recently agreed to allow us to release the aggregate CAMEL5 variable, which does not reveal individual bank ratings, with a five-year lag. Thus, the CAMEL5 series used in this study is available from the authors upon request.

2. The FDIC produces a "problem bank" series that is made public. This series reports assets in problem banks, essentially those with CAMEL ratings of 4 or 5 . The series first became available in 1990, although the series contains information back to 1984. Peek, Rosengren, and Tootell (2000) explore whether the FDIC "problem bank" series contains all of the information in CAMEL5. They find that even after controlling for the problem bank series, CAMEL5 still contains confidential information that improves commercial forecasts of economic activity.

3. The GDP series used is the final GDP of the U.S. Bureau of Economic Analysis, which represents the final GDP measure before the benchmark. This assumes that forecasters are predicting the actual underlying activity rather than trying to forecast any of the preliminary estimates based on more incomplete data. There were two benchmark revisions during our sample, 1986:I and 1992:I. This poses a potential problem because at the time of the benchmark, some of the forecasts are based on the old benchmark, while actual GDP as reported by the BEA is reported using the new benchmark. However, the major results reported in this paper are not sensitive to the exclusion of those observations.

4. The timing convention of using the middle month of each quarter may be made clearer using an example. For the February forecast date, the one-quarter-ahead forecast would be for the period from January 1 to March 31. At that time, all the forecasters would have the BEA's advance estimate of GDP for the previous quarter.

5. However, the sample is unbalanced, since the 1978:II and 1979:II observations for RSQE are unavailable.

6. Owing to data availability for the forecasts, the panel data set is unbalanced. In addition to missing the 1978:II and 1979:II RSQE observations, Green Book forecasts for nonresidential investment, producers' durable expenditures, residential investment, and consumption begin in 1978:III, and for the change in business inventories and exports in 1986:I.

7. The recession quarters are selected based on the quarter of the actual values, not based on the quarter in which forecasts are made. Thus, for a forecast made in quarter $t$ for GDP growth in quarter $\mathrm{t}+\mathrm{i}$, the quarter will be designated as a recession quarter if the economy was in a recession during quarter $\mathrm{t}+\mathrm{i}$. 
8. In the case of a supply shock caused by weakness in the banking sector, government policy can help reverse the shock. However, the savings and loan bailout in the United States occurred over an extended period of time, and fiscal policy in Japan has yet to reverse the problems caused by its banking crisis.

9. Even if the bank health proxy contained confidential information about loan demand, knowledge about the level of aggregate demand in the economy is impossible to keep confidential for long, since forecasters quickly learn of the state of the economy as current data are released.

10. Note that a confidential demand shock should have effects that are temporary, not only because the shock's effect on the real economy dissipates, but because the relevant information is so much harder to keep confidential; if the economy is weak, then aggregate data will soon be released that reveal that weakness. 